\title{
ENTRE PAISAJES CULTURALES Y MASSMEDIÁTICOS
}

Sobre Mariana Catalin. Con los ojos bien abiertos. Bizzio, Chejfec y Babel. Rosario: Fiesta E-diciones, 2014.

Mariana Giordano

UNR

CONICET

El libro propone una lectura cruzada entre determinados textos ficcionales de Sergio Chejfec y Sergio Bizzio. Catalin diseña su manera de pensar el presente a partir de las discusiones que tuvieron lugar en Babel. Revista de Libros. La autora asume el riesgo de inmiscuirse en el horizonte de problemas que se produjeron en el seno de la revista, para proyectar lecturas literarias que marcan una diferencia radical con la modernidad.

Por este camino, se interroga al presente desde lo que sería el manifiesto de Babel, fechado en 1988 y con firma de Martín Caparrós y Jorge Dorio. De allí, Catalin extrae el título: "Con los ojos bien abiertos". Esta frase ilustra el modo de operar críticamente haciendo alusión al juego de truco. La ficción aparece cuando no hay cartas y no hay señas más que la del "ciego". Entonces, se juega sin cartas pero con los ojos bien abiertos.

Este guiño al lector que supone mixturar una actitud del juego con la crítica literaria tiene una justificación: el final de la literatura. El problemático tópico del fin de la literatura se enuncia desde el comienzo y es un punto de reflexión. Los argumentos se contorsionan a lo largo de las páginas, 
encontrando ribetes inesperados en donde la ficción logra salir airosa y sobrevivir interviniendo.

Una de las apuestas más interesantes de la trama argumentativa es la creación de una perspectiva temporal singular que permite vislumbrar la particularidad de estas series poéticas. Al estar situadas en un entre épocas se cifran las tensiones que hacen progresar la escritura y atraviesan tres cuestiones fundamentales: el realismo, los límites de la literatura y la vuelta a lo autobiográfico. Así, el marco desde el cual se ingresa a las ficciones reformula debates pilares del presente, en torno a los discursos del fin como propios de la modernidad (Bourriaud), para proponer ese espacio bisagra entre un antes y un después del fin. Las problemáticas son abordadas desde la consigna de poner en tela de juicio ciertas lecturas acerca de la posmodernidad.

La elección de Bizzio y de Chejfec es la prueba de lo apropiado del enfoque para el estudio de escrituras tan diferentes como convergentes. Es constante la búsqueda de otros parámetros para expresar el modo de intervención que se observa en estas poéticas. Ambos "escritores de Babel' se inscriben en un tejido de fuerzas que propone la lectura de la revista. Ésta aporta un contexto de época que pone en relación sus trabajos con otros escritores de la generación: Alan Pauls, Daniel Guebel, César Aira, Matilde Sánchez, etc.

Si bien el corpus está compuesto por novelas de Chejfec y de Bizzio, la tesis de Catalin puede ser extensiva para leer un estado actual más amplio, debido a que los ejes tratados se desprenden de las discusiones que dieron sustento a la revista. Además, este dispositivo de lectura favorece el diálogo con teóricos de diversos dominios como Jean-Luc Nancy, Hal Foster, Lev Manovich, Baudrillard, Frank Kermode y Néstor García Canclini, sólo por mencionar algunos. 
El recorrido del libro incluye los siguientes pares de ficciones: Boca de Lobo y Rabia, Baroni: un viaje y Realidad y Mis dos mundos y Era el cielo (las primeras de Chejfec y las segundas de Bizzio). A los que se suman otras ficciones como Planet de Bizzio y El aire y Lenta biografía de Chejfec. De esta forma, la lúcida organización de los capítulos atraviesa cada problemática, al mismo tiempo que argumenta la hipótesis y abre universos posibles segregados por la ficción. Por ejemplo, así demuestra que a Sergio Chejfec el realismo le permite hablar sobre el final de la novela y articular el concepto de relato.

La categoría de paisaje es tomada de la teoría de la ruptura de Arjun Appadurai. Catalin se apoya en un ensayo de Chejfec, "Fábula política y renovación estética", para pensar los paisajes en sus novelas. De allí escoge la idea de paisajes culturales que propone el escritor: las "realidades humanas" deben intervenir en la ficción ampliando el espectro de acción. La lectura de Chejfec que propone Catalin expone la interrelación entre su producción narrativa y ensayística. Para pensar la serie de Bizzio, Catalin postula que la proliferación de imágenes construye los denominados paisajes massmediáticos televisivos. La lógica de las imágenes en el capitalismo desorganizado funciona como umbral de una relación singular con lo actual.

Para abordar el problema del realismo y las lógicas del fin, Catalin escoge Boca de Lobo de Sergio Chejfec y Rabia de Sergio Bizzio. En el primer caso, recupera lecturas canónicas dentro del campo intelectual argentino, como son las de Beatriz Sarlo y Josefina Ludmer. Pero no con el propósito de mostrar su antagonismo sino para señalar una continuidad de la propuesta de Sarlo (quien lee como un detalle que los barrios obreros son villas miserias), en la lectura de Ludmer. La singularidad de la relación con la fábrica le permite al texto referirse a su propio fin. Este argumento también se relaciona con el planteo de 
Isabel Quintana, para quien la tensión temporal admite relaciones de intercambio premodernas.

Para leer a Rabia de Bizzio, reflexiona desde el aporte de Florencia Garramuño, quien enfoca, en torno al multiculturalismo, una mirada documental sobre la relación entre la clase baja y la clase alta en un nuevo contexto. La propuesta de Catalin muestra el reverso del realismo en la flexión que crean ambos textos, hasta distanciarlos de las claves modernas de observación para experimentar con las tensiones que abre la literatura.

El singular temporal se explica en Boca de Lobo, como un tiempo que engulle (a diferencia del tiempo situable de Rabia) y elimina cualquier referencia temporal concreta. Catalin hilvana las líneas de lectura que traza desde ese dispositivo específico: el entre de los paisajes culturales. Así mismo, el realismo es la manera de mostrar ese singular que implica la tensión del tiempo que se está convirtiendo en otro.

En Realidad de Bizzio la lógica televisiva se instala como modo de actuar y como procedimiento. Por lo tanto, el interés por la vida de artistas y por participantes de reality shows hace que ingresen el arte plástico y el audiovisual en el seno del debate acerca de los límites. La articulación se da a partir de la proliferación de imágenes y de allí el pasaje al mundo mediático: de la telenovela al reality show. Se trata de la construcción de un verosímil en los bordes de la realidad. En el caso de Baroni: un viaje el carácter performático que adopta el narrador invita a confrontar una vida de artista con la práctica de escritura reflexiva que lleva adelante la narración.

La posibilidad del fracaso, latente en Mis dos mundos y en Era el cielo, da vueltas los rasgos autobiográficos y traza una línea de fuga por la escritura literaria. El lugar del narrador permite experimentar "realidades humanas" que descentran su 
posición. El texto de Chejfec se abre hacia la reflexión sobre su propia poética, mientras que en Bizzio se articula una lógica más ambigua acerca de la referencialidad del yo, lo que permite ponerla en diálogo con la propuesta de Alberto Giordano sobre el giro subjetivo de la literatura argentina actual y los matices entre "novelas del yo" y "escrituras del yo".

En El aire de Chejfec, la premonición desde la que se narra la historia sugiere un presente suspendido desde el que se desprende un sentido de "futuridad", que será puesto a prueba desde un sistema particular de intercambio. De las diversas lecturas que genera el lugar de las fotografías en su narrativa, se abre la discusión sobre la reformulación del realismo, en consonancia con la propuesta de Luz Horne, quien lee en El aire el uso de procedimientos vanguardistas para generar efectos de realidad. Sin dudas, se trata del deseo vanguardista de producir discontinuidad con el fin de captar la temporalidad contemporánea de un modo más preciso.

El lugar y la naturaleza de "lo documental" es un tópico común a ambas series poéticas. La tensión entre lo abstracto y lo material, la pérdida de fronteras nítidas y el cruce de temporalidades son centrales para pensar el modo de relación del arte con lo actual. Las lógicas de construcción son desbordadas por los mismos relatos, lo que deja entrever aquello que Catalin postula como potencial del entre épocas y que se visualiza en tanto paisaje cultural y massmediático.

La investigación que presenta Mariana Catalin constituye un aporte sobresaliente dentro de los estudios críticos en Argentina. El ensayo muestra una lectura atenta y minuciosa de problemáticas cruciales, como el realismo, la modernidad/posmodernidad y el fin de la literatura. Por todo esto, la tesis se corresponde a preguntas formuladas con ingenio: ¿cuál es la relación entre realismo y fin? La propuesta no 
se cierra en determinismos ni en clasificaciones que acotan las diversas entradas de lectura, sino que la meta está proyectada en ver, con los ojos bien abiertos, los atajos que la literatura puede aún encontrar para seguir experimentando sus posibilidades, siempre contemplando las contradicciones propias de un presente inestable. 